\title{
Let's Not Forget Ecological Literacy
}

\section{Matthew Ortoleva - Worcester State University}

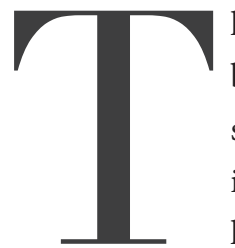

he contributors to the first issue of Literacy in Composition Studies (LiCS) begin to do the important work of historicizing and contextualizing literacy studies in relation to composition-rhetoric; however, missing from the inaugural issue is any explicit discussion of ecological literacy. By ecological literacy, I am referring to the ways in which humans understand their interconnectedness to biotic and abiotic communities. More specifically, ecological literacy means understanding material and discursive relationships, and how these relationships are created, maintained, modified, solidified, and radically changed by acts of language. That acts of language have direct impact on physical environments and can have significant consequences for life on the planet-ours as well as the multitude of other species with which we share this placeanchors my definition of ecological literacy by connecting the discursive and the material, natural world. The inauguration of this new journal offers an opportunity to reconsider the importance of ecological literacy and ecological thought, and how these concepts might bear upon the field of composition-rhetoric.

Above, I say no explicit discussion because there are indirect references to ecological literacy woven throughout the inaugural issue. There is an implicit social ecological literacy, or socioecological understanding, evident in the first issue as illustrated in the LiCS mission statement. The LiCS mission statement recognizes literacy as "a fluid and contextual term," which "can name a range of activities from fundamental knowledge about how to decode text to interpretative and communicative acts" (v). The mission statement also asserts that literacies "are linked to know-how, to insider knowledge, and literacy is often a metaphor for the ability to navigate systems, cultures, and situations," and that "[a]t its heart, literacy is linked to interpretation-to reading the social environment and engaging and remaking that environment through communication" (v). The specific mention of the "social environment" mutes the importance of a material dimension of ecological literacy, a dimension to which we must attend.

There are further indirect references to ecological literacy beyond the mission statement. Donna Qualley, for example, suggests that through “volition, will, and desire," human beings have at least some ability to navigate "the multitude of forces-political, institutional, economic, cultural, and social-that surround them" (50). For Qualley, human agents are subjected to a web of interrelated 
forces-institutional, cultural, social, and economic forces that we understand as connected in an abundance of ways, and it is through will and desire, and I would add everyday rhetorical abilities and sensitivities, that human agents manage to take some control of their lives. Eli Goldblatt admittedly "can't get over [his] own penchant for seeing literacy as human behavior always nested within relationships" (54). Ecology is the science of relationships. Consider the first definition offered by German biologist Ernst Haeckel in 1870. He wrote:

By ecology we mean the body of knowledge concerning the economy of nature-the investigation of the total relations of the animal both to its inorganic and to its organic environment including above all, its friendly and inimical relations with those animals and plants with which it comes directly or indirectly into contact-in a word, ecology is the study of all those complex interrelations referred to by Darwin as the conditions of the struggle for existence. (qtd. in McIntosh 7-8)

Both Goldblatt and Qualley recognize the ecological character of human existence, an existence based on networks and relationships of words, symbols, and material realities.

It is Robert Yagelski who most strongly invokes the ontological relationship between symbols and the material, natural world. He writes:

Lately, prompted by the need to reconcile my embrace of Freire's transformative vision with my own growing uneasiness about the role that western literacy seems to play in the ongoing destruction of our planet [ ... ] I have come to see that in addition to its social consequences, literacy-more specifically, writing-also has ontological consequences. Indeed, the social consequences of literacy might well arise from its ontological implications. (emphases in the original, 58)

Yagelski, like Kate Vieira-to whom he is responding in his essay in the inaugural issue-is concerned with the consequences of literacy, particularly the possible ontological consequences felt in the material world. Yagelski points to the fact that Freire's pedagogy is a literacy of liberation designed to help peasants overcome political and economic oppression (56). Interestingly, in her discussion of a place-based writing pedagogy, Arlene Plevin also invokes Freire's pedagogy of liberation to prevent the oppression of the natural world, as she extends Freire's idea of being "fully human" to include "awareness, respect, and consciousness for nonhuman" (153). Both Yagelski and Plevin recognize the relationship between literacies and oppressive acts that adversely affect human agents and their ecological communities, the very communities we depend upon for wellness and survival.

Arguably, Kenneth Burke is the first in rhetorical studies to raise the idea of ecological literacy when he suggests in Attitudes Toward History that ecology is one science to which we will need to pay more attention in the future. Burke's ecological perspective on language has long been a topic for rhetorical scholars. Randall Roorda refers to Burke as a "critical ecologist" who employs adaptive terminologies in the study of symbol use ("KB in Green" 173). Marika Seigel points out that during the time Burke was writing Attitudes Toward History, the science of ecology was well established and "increasingly coming to the forefront of public consciousness and debate" (389). Burke certainly 
would have been well aware of the ecological devastation that led to the Dust Bowl and the ecological conversation surrounding it (389). As the 1930s was a decade when ecology as a science was growing in scope, and when ecological communities, particularly in the Midwest, were experiencing catastrophic change, Burke would not have been a stranger to the theories and terministic screens of ecology. Despite its rise, ecology at the time Burke penned Attitudes Toward History was still a fairly young science, and that Burke drew from ecology to formulate his theories, as many scholars contend, is quite remarkable and marks the beginning of ecological thought in rhetorical studies.

Since Burke, the field of composition-rhetoric has developed a bit of a duality in the way it engages with ecological thought. Some scholars adopt ecological concepts in very broad ways, often wholly metaphorical. Others hold more closely to the actual goals and concerns of the discipline of ecology, i.e., the preservation, protection, and health of our physical environment. Following some half-century after Burke, Marilynn Cooper postulates an "ecology of writing" using the metaphor of a web to demonstrate the interconnectedness of writers and their environments. Margaret Syverson theorizes writing emerging from complex systems where writers engage agents and structures within social, physical, and embodied environments. Jenny Edbauer's distributed rhetorical ecologies expand beyond discrete rhetorical situations toward the fluidity of rhetorical exchanges. And for Dyehouse, Pennell, and Shamoon ecology, along with "writing environments," is a generative conceptmetaphor; however, they settle finally on "environmental literacy" as a way to better understand and teach students to navigate the material and digital environments in which they write. Dyehouse, Pennell, and Shamoon connect information ecologies, which "highlight humans' interaction with technologies" and digital literacy, but, admittedly, they invoke ecology largely as metaphor, despite their interest in the materiality of literacy.

Scholars working in the subfield of environmental rhetoric draw a more direct connection to ecological degradation and have been interested in the scientific discourse of ecology for some time. For instance, Jimmie Killingsworth and Jacqueline Palmer suggest that "the environmental dilemma is a problem generated by the way people think and act in cultural units" (3) and analysis of environmental issues can identify "various discourses on the environment before they are galvanized by dichotomous political rhetoric" (10). Sharon McKenzie Stevens works with the concept of "socioecology" and defines it as "the creation of [a] dialogic space and the material practices that accompany that dialogue" (65). Stevens uses socioecology as a means for examining land-use dialogue between ranchers and environmentalists in Arizona. These scholars, along with Derek Owens, Mark Long, and Paul Lindholdt, among others, have stressed the need for an environmentally-sensitive composition, or have argued that composition studies is a prime location to begin to address the exigency of environmental degradation.

The duality in the way scholars of composition-rhetoric treat the concept of ecology has been very productive, but ecological thought devoid of a material, natural dimension is potentially problematic, and scholars and teachers need to be exceedingly cautious when using ecology metaphorically without its connection to real, natural places. Although the social and ecological are often treated as 
separate, as geographer Bruce Braun points out in his meta-analysis of urban geography scholarship, they are not (642). All human activities have an ecological component to them.

Attempting to straddle this duality of ecological thought in composition-rhetoric, Dobrin and Weisser, in their formulation of ecocomposition, offer an environmentally-sensitive, "green" model of composition while also calling for ecological models of discourse so as to understand its interrelated and networked systems. Dobrin and Weisser define ecocomposition as "the study of the relationship between environments (and by that we mean natural, constructed, and even imagined places) and discourse (speaking, writing, and thinking)" (Natural 6). Separately, Dobrin suggests that ecocomposition "is the investigation of the total relations of discourse both to its organic and inorganic environment and to the study of all the complex interrelationships between the human activity of writing and all of the conditions of the struggle for existence" (13). For Dobrin and Weisser, humans inhabit two spheres: the biosphere, which is the physical environment and skin that sustains all life on the planet; and the semiosphere, which consists of discourse and our symbolic action that shapes our existence and allows us to make sense of our world ("Breaking" 574). For Dobrin and Weisser, the relationship between these two spheres (environment and discourse) is reciprocal and dialogic ("Breaking" 574). Dobrin and Weisser's formulation of ecocomposition, then, connects acts of textual composition with the myriad of environments human agents inhabit.

According to Dobrin and Weisser, however, the scope of ecocomposition expands beyond material environments to imagined, social, and cyber environments as well and, as theorized, not always in a manner concerned with the material, natural world. Indeed, ecocomposition, depending on how it is enacted, can treat ecological concepts in a manner consistent with Haeckel's original and still widely accepted definition of ecology, or it can treat ecology as a metaphor with no real connection to the natural world, again creating a duality in the way ecology is enacted. Ecocomposition is a generative concept and can result in critical practice; however, its broad treatment and bifurcated nature can remove it from the ecological exigence currently affecting all levels of the biosphere, micro and macro. As a result, the focus on the human habitation of the biosphere is lost, as is the connection between the semiosphere and the biosphere originally suggested by Dobrin and Weisser. Ecocomposition is and will remain an important and productive concept in composition-rhetoric; however, ecological literacy is, perhaps, a more powerful tool for framing issues of ecological and environmental concern. Ecological literacy can also serve as the foundation for literate acts that seek to address the human relationship to the natural world and allow for a deep and critical understanding of the relationship between the two spheres.

Dobrin and Weisser credit Randall Roorda and his 1998 Conference on College Composition and Communication (CCCC) panel presentation for first using the term ecocomposition and, perhaps more importantly, for calling for the move toward ecological literacy. This move from "literature to literacy" gets its fullest treatment in Roorda's Dramas of Solitude: Narratives of Retreat in American Nature Writing, where questions of literacy and literacy studies are woven through the entire text. Roorda studies key narratives of retreat-including those of Muir, Thoreau, Van Dyke, and Berry- 
but moves beyond representations of nature or ecocritical analysis. Roorda asks questions concerning the ethical implications of these texts, what purpose they serve, how writers form identities around places, and how places are socially constructed. In Christopher Keller's formulation, Roorda also raises important questions concerning "how writing, or composing, differs in solitude and society" and "how rhetoric and composition as a discipline might be restructured by new examinations, definitions, and uses of these texts" (Keller 511). A key feature of Roorda's Dramas of Solitude is his desire to put these narratives of retreat into the service of developing students' ecological literacy. As he turns in the last chapter to student writing, Roorda writes:

I want to raise issues relevant to my thesis in the realm of general education, where knowledge and attitudes transcending specialization are presumably formed. A key issue concerns the significance of generically constituted personal experience of nature for writing and literature instruction, environmental education, and the cultivation of an "ecological literacy" that would comprehend both. (206)

Hence, Roorda's ecological literacy would connect the discursive sphere of writing and literature with our environment, our biosphere. Roorda also sees the potential for ecological literacy to serve as a bridge between orality and writing, one of the "foundational dichotomies" with which, according to Graff, literacy studies still struggles (16).

Roorda's ecological literacy also includes what he calls "participatory reading," which is as much about the intent of the use of the text by the author as it is about the way the text is consumed. A participatory reading can be anticipated by an author (Roorda uses Henry David Thoreau’s Katahdin as an example) and is written for those who may "engage in or contemplate such a trip [ ... ] for the purpose of emulating, comparing notes with, vicariously participating in the journey narrated" (32). Such a text, according to Roorda, may well find its way into the backpack of a traveler and serve as a companion on the trip. Such a text reorients a reader and "presumes their ability to replicate the experience upon some terms or others, and many of the book's readers are out to do just that" (32). A participatory reading connects writer, reader, text, and the material world, often through direct experience, and can make connections between the types of texts students consume and the types of texts they produce (Keller 516).

It is important to note that Roorda's notion of ecological literacy progresses from David Orr's definition of the concept. Orr champions an ecological literacy that directly addresses the exigency of environmental degradation, and his work in the area of environmental studies has influenced several disciplines, including composition-rhetoric. Orr's definition of ecological literacy is not necessarily rooted in theories of language, but rather an understanding of Earth's systems, and a sense of wonder that comes from direct experience with the natural world. Still, Orr hints at important characteristics of ecological literacy that smack of the type of literacies that are often associated with composition studies, such as the ability and desire to read critically and understand how the "domination of nature found in the writings of Bacon, Descartes, and Galileo" or as portrayed in Frankenstein or Moby Dick has helped construct a culture that is indifferent to environmental destruction (93). Orr, however, 
is concerned with the overhaul of the entire education system, including liberal arts education, and does not address the deeper socially-constructed relationship between humans and their ecological communities, a relationship based in symbolic action that Roorda and others address. Importantly, then, Roorda extends Orr's definition of ecological literacy by getting to its roots in acts of language, thus adding an important and neglected aspect of such literacy.

As I hope I have demonstrated, ecological literacy has long been a part of composition-rhetoric, albeit peripherally, and holds considerable promise as a critical practice for the field. What we must do now as teachers and scholars is focus on the impact our literacy practices have on our ecological communities and the consequences of ignoring such impact. As James Berlin suggests, "Ways of living and dying are finally negotiated through discourse" (89). Dobrin and Weisser argue that "one of ecocomposition's very reasons for being is to inquire into ways to bring about political, social, and/or environmental change-both practical, theoretical, and epistemological" (Natural 86). If literacy and composition studies are connected, as the very existence of this journal suggests, so too are ecocomposition and ecological literacy, and this relationship must be more fully explored and developed. If humans use language to construct cultures and societies, to create and affect places, to navigate the world around them, and to affect this materiality and all the dimensions of the nonhuman world, then ecological literacy is essential. If Vieira finds compelling the question, "What are the consequences of literacy?" and determines that "Composition Studies is an ideal disciplinary space from which to approach it," so too might ecological consequences be recognized through ecological literacy (26).

To have an ecologically literate populace is to have a populace that understands the way language is networked across dimensions of human activity, and also the way these networks of language affect the ecological communities to which we belong. The consequences are real: increased storm activity; the loss of biodiversity; poisons in our food, water, and air. As Vieira suggests, "Literacy can index race, culture, age, gender, class, capitalism, identity; it leeches the meanings that organize our lives" (26). All of these constructions have an ecological dimension. We must remember we only know the natural world through language, and all places are part natural. Human beings can no more step outside their ecological communities than they can their structures of language.

As the field considers the complexity and, I hope, the necessity of ecological literacy, the following questions may help guide us: How might ecological literacy connect with larger social issues, such as race, poverty, and class struggle? How might ecological literacy be informed by bioregionalism? How might local discourses affect local ecologies? How can ecological literacy help us move from anthropocentric to biocentric to ecocentric and finally to socially and environmentally just societies? By pursuing these questions and others, ecological literacy becomes a potential tool against structures of oppression and is put into the service of creating healthy, just, and democratic communities. After all, injustice often has a neglected ecological dimension. Ecological literacy will enable ecological thinking, which will in turn enable the ability to see networks-networks of discourse, networks of power, networks of oppression, and networks of degradation. 


\section{WORKS CITED}

Berlin, James A. Rhetorics, Poetics, and Cultures: Refiguring College English Studies. West Lafayette: Parlor P, 2003. Print.

Braun, Bruce. "Environmental Issues: Writing a More-Than-Human Urban Geography." Progress in Human Geography 29.5 (2005): 635-50. Print.

Burke, Kenneth. Attitudes Toward History. Berkeley: U of California P, 1984. Print.

Cooper, Marilyn M. “The Ecology of Writing." College English 48.4 (1986): 364-75. Print.

Dobrin, Sidney I. "Writing Takes Place." Weisser and Dobrin 11-25.

Dobrin, Sidney I., and Christian R. Weisser. "Breaking Ground in Ecocomposition: Exploring the Relationships Between Discourse and Environment.” College English 64.5 (2002): 566-89. Print.

---. Natural Discourse: Toward Ecocomposition. Albany: SUNY P, 2002. Print.

Dyehouse, Jeremiah, Michael Pennell, and Linda K. Shamoon. "Writing in Electronic Environments'

A Concept and a Course for the Writing and Rhetoric Major." College Composition and Communication 61.2 (2009): 330-350. Print.

Edbauer, Jenny. "Unframing Models of Public Distribution: From Rhetorical Situation to Rhetorical Ecologies." Rhetoric Society Quarterly 35.4 (2005): 5-24. Print.

Goldblatt, Eli. "Locating Ourselves and Our Work" Literacy in Composition Studies 1.1 (2013): 53-55. Print. Graff, Harvey. “The Legacies of Literacy Studies.” Literacy in Composition Studies 1.1 (2013): 15-17. Print.

Keller, Christopher J. "Review of Dramas of Solitude: Narratives of Retreat in American Nature Writing." JAC 19 (1999): 511-16. Print.

Killingsworth, Jimmie M., and Jacqueline S. Palmer. Ecospeak: Rhetoric and Environmental Politics in America. Carbondale: Southern Illinois UP, 1992. Print.

"LiCS Mission Statement." Editorial. Literacy in Composition Studies 1.1 (2013): v. Print.

Lindholdt, Paul. “Restoring Bioregions Through Applied Composition.” Weisser and Dobrin 235-52.

Long, Mark, C. "Education and Environmental Literacy: Reflections on Teaching Ecocomposition in Keene State College's Environmental House." Weisser and Dobrin 131-46.

McIntosh, Robert P. The Background of Ecology: Concept and Theory. New York: Cambridge UP, 1986. Print.

Orr, David W. Ecological Literacy: Education and the Transition to a Postmodern World. Albany: SUNY P, 1992. Print.

Owens, Derek. Composition and Sustainability: Teaching for a Threatened Generation. Urbana: NCTE, 2001. Print. Refiguring English Studies.

Plevin, Arlene. “The Liberatory Positioning of Place in Ecocomposition: Reconsidering Paulo Freire." Weisser and Dobrin 147-62.

Qualley, Donna. “After Words: Some Thoughts.” Literacy in Composition Studies 1.1 (2013): 50-52. Print.

Roorda, Randall. Dramas of Solitude: Narratives of Retreat in American Nature Writing. Albany: SUNY P, 1998. Print.

---. "KB in Green: Ecology, Critical Theory, and Kenneth Burke." Interdisciplinary Studies in Literature and Environment 4.2 (1997): 39-52. Print.

Seigel, Marika A. “'One Little Fellow Named Ecology': Ecological Rhetoric in Kenneth Burke's Attitudes toward History." Rhetoric Review 23.4 (2004): 388-404. Print.

Stevens, Sharon McKenzie. A Place for Dialogue: Language, Land Use, and Politics in Southern Arizona. Iowa City: U of Iowa P, 2007. Print.

Syverson, Margaret A. The Wealth of Reality: An Ecology of Composition. Carbondale: Southern Illinois UP, 1999. Print.

Vieira, Kate. “On the Social Consequences of Literacy." Literacy in Composition Studies 1.1 (2013): 26-32. Print. 
Weisser, Christian R., and Sidney I. Dobrin, eds. Ecocomposition: Theoretical and Pedagogical Approaches. Albany: SUNY P, 2001. Print.

Yagelski, Robert P. "Literacy and Consequences: A Response to Kate Vieira." Literacy in Composition Studies 1.1 (2013): 56-59. Print. 